\title{
THE COMPARISON OF SELECTED LEGAL ASPECTS OF INSURANCE PRODUCTS ON THE POLISH AND BRITISH MARKETS
}

\begin{abstract}
Author of this thesis has undertaken the research about Polish and English legal system and regulations that are essential for insurance market. This topic is not very popular in literature, because it is hard to find the comparison of Polish and English regulations that establish the conditions on which third party liability vehicle insurance contracts are concluded. That issue is very important to determine the level of development of the Polish insurance market. Before 1989 insurance market in Poland was monopolized by two companies. So it could be said that it is rather young, and may be less developed than English. The aim of that thesis has been achieved. The studies show that there are several significant differences in Polish and English legal system, but regulations do not follow changes of the insurance market in both countries. At the beginning of the thesis the author presented history of risk management and insurances. Next moved to analysis of legal regulations that are essential for compulsory vehicle insurance in Poland and England.
\end{abstract}

Keywords: third party liability, insurance, obligatory insurance.

\section{INTRODUCTION}

Every possessor of a motor vehicle in Poland and in England is obliged to have a third party insurance. So the topic in this thesis should be interesting for anyone, who uses a car. The aim of this type of insurance is to ensure that damages resulting from an accident can be compensated. In every country there are some rules and law regulations that are different, and make the insurances not similar. The aim of this thesis was comparison of third party vehicle insurance system in Poland and England. The result of this thesis should be the proposal of changes in regulations and conditions that can improve insurance system in Poland and England.

The aim of this thesis was achieved by deep analysis of law regulations in Poland and England and terms and conditions on which insurance contracts are concluded. This paper is based on regulations that was valid at the end of 2014 and at the beginning of 2015. It is very hard to find papers that present similar subject.

*Kancelaria Brokerska WTB Sp. z o.o. Dyrektor likwidacji szkód. sebastian.barszowski@, yahoo.com 
Most of articles describe legal acts, but do not compare them with analogous regulations in other countries. It was very hard to achieve the aim of this thesis, because solutions applied to deal with the same problem are sometimes different in Poland and England. Legal system in Poland and in England have different historical roots. In Poland if there is something not clear in law regulations it may be interpreted individually by different courts. In England exists the rule of precedent, so legitimate judgment is treated as a source of law, and has to be taken into consideration in analogical issues by other courts.

This thesis is divided into three parts. In the first one the author illustrates the history of insurance in Poland and England and outline the role of insurance in economy of both countries. This part is an introduction for further consideration, because it is very important to understand the historical background that determines the insurance system. Second part of this paper is an analysis of legal regulations and comparison of law regulations that are crucial for the insurance market. The last part of this thesis is a study that shows the differences in the functioning of third party vehicle insurance in Poland and England.

\section{LEGAL BACKGROUND FOR INSURANCE IN POLAND AND IN ENGLAND AND BASIC TYPES OF INSURANCES}

\subsection{General description of law regulations of insurance market in Poland and the England}

The main source of law in Poland is the Constitution of the Republic of Poland of 2 April 1997 but it does not include statements that refer to insurances. The functioning of the insurance market in Poland is regulated in acts subordinated to The Constitution. The most acts referring to the insurances were adopted in 2003 to harmonize Polish regulations with European law. The most important act is The Insurance and Reinsurance Activity Act of 11 September 2015 (Dz. U. 2015, poz. 1844). This act establishes the regulations on insurance supervision and conditions on which insurance companies can carry out their activities (provisions of insurance companies, financial requirements and conditions of cross border insurance). Another important act for insurance activity is The Act of 22 May 2003 on Insurance Intermediation (Dz. U. 2003, nr 124, poz. 1154). The act sets out the conditions on which insurance agents and brokers can work including insurance commission, registration, qualifications and supervision of insurance intermediaries. Also Title XXVII of the Third Chapter of the Polish Civil Code on insurance contracts contains insurance contract law, such as requirements for form, conditions for conclusion and termination of insurance contracts, rights and obligation of the parties, and statute of limitation for claims (Zimoch-Tucholka, 2008). Also very important for insurance market is Act of 22 May 2003 on 
Compulsory Insurance, the Insurance Guarantee Fund, and the Polish Motor Insurance Bureau (Dz. U. 2003, nr 124, poz. 1152). This act defines the rules of concluding compulsory insurance contracts and their complementation, the way to control the fulfillment of the obligation to conclude the compulsory insurance contracts, and operation of the Insurance Guarantee Fund and the Polish Office of Vehicle Insurers. The responsibilities and competences of the Financial Supervision Commission were established by the Act of 21 July 2006 on Financial Market Supervision. The Marine Code of 18 September 2001 establishes regulations that are essential for marine insurances.

English legal system is slightly different from Polish. In Poland all regulations are codified and courts may only interpret regulations while in England exists precedential authority of court decisions. So in the UK courts have the legislative power. The biggest advantage is that similar facts are treated identically according to the situation and problem solved once does not exist as a problem anymore. In Poland situation is much more complicated because the same regulation may be interpreted by a court differently on different occasion. In both countries there are several acts which are basic for insurance market. In the UK The Customer Insurance Act 2012 establishes the relation between insurers and the individuals who enters into a consumer insurance contract, or proposes to do so. It is important to notice that insurance for individual consumer is not for business use (The Consumer Insurance Act - legal interpretation 2014). Schedule 2 of the Act sets out rules for determining status of agents. The Financial Services and Markets Act 2000 sets out the objectives and duties of the Financial Services Authority (FSA). FSA is established as a market regulator for insurance and financial business (Financial Services and Market Act 2012). The main part of this act is not valid because after the financial crisis was implemented a new regulatory framework by The Financial Services Act 2012. FSA was replaced by two new regulatory authorities: The Prudential Regulation Authority (PRA) as a body which oversee the financial health and stability of financial services firms and the Financial Conduct Authority (FCA) which maintains the integrity of financial market and regulates financial firms providing services to consumers (Insurance Journal 25.12.2014, 11: 17). The act applies to the whole financial market and it is difficult to find direct references to insurances, however insurance business as a part of financial market is a subject of this act. Third Parties Act 2010 makes provision about the rights of third parties against insurers of liabilities to third parties in the case where the insured is insolvent. This act replaced the Third Parties (Rights against Insurers Act) 1930. The new regulation should help to establish liability of the insured much faster. For example according to the act from 1930 in most cases liability may be established only by the court. In new act the procedure is much easier and sometimes quicker (Bourne, 2014). For owners of motor vehicles essential is section 143 of The Road Traffic Act 1988 which requires drivers to have a third party liability insurance: 
A person must not use a motor vehicle on a road or other public place unless there is in force in relation to the use of the vehicle by that person such a policy of insurance or such a security in respect of third party risks as complies with the requirements of this Part of this Act,

and

A person must not cause or permit any other person to use a motor vehicle on a road or other public place unless there is in force in relation to the use of the vehicle by that other person such a policy of insurance or such a security in respect of third party risks as complies with the requirements of this Part of this Act. (The Road Traffic Act 1988)

If a driver does not have such an insurance he makes an criminal offence. The similar situation is in Poland. The Act of 22 May 2003 on Compulsory Insurance, the Insurance Guarantee Fund, and the Polish Motor Insurance Bureau in Poland sets out that all users of a vehicle need to have a third party liability insurance.

In England there are also two other acts that have a fundamental influence on insurance market. The Insurance Companies Act 1988 (repealed) sets out the restrictions on carrying on Insurance Business and the regulation of insurance companies. The Marine Insurance Act 1906 establishes requirements for marine insurance contracts.

\subsection{Comparison of regulations that refer to the vehicle insurance in The Road Traffic Act 1988 and Act of 22 May 2003 on Compulsory Insurance, the Insurance Guarantee Fund, and the Polish Motor Insurance Bureau (The Compulsory Insurance Act)}

In England aims and rules of compulsory motor third party insurance are set out in VI Part of The Road Traffic Act 1988 and the act refers only to users of motor vehicles. In contrast Polish Compulsory Insurance Act refers not only to vehicle insurances but also to compulsory civil liability insurance of farmers and compulsory insurance of buildings belonging to the farm from fire and other casualties and also establishes the aims and principles of operation of Insurance Guarantee Found and Polish Motor Insurance Bureau.

Both acts impose an obligation to own third party insurance by motor vehicle user. In the UK the duty refers directly to the driver but in Poland the obligation refers to the holder of the vehicle. Art 23 of Polish Compulsory Insurance Act states:

The holder of a motor vehicle is obliged to have a contract of compulsory liability insurance of motor vehicle owners for damages caused in association with the movement of the vehicle owned by him. (The Act of 22 May 2003 on Compulsory Insurance, the Insurance Guarantee Fund, and the Polish Motor Insurance Bureau Art. 23)

In Poland every vehicle which uses roads or other public places must have an insurance including vehicles which do not have registration numbers like bulldozer 
or excavator. There are only two exceptions of that rule. Military vehicles that belongs to Polish Military Forces and its foreign allies accepted by international agreements. Second exception refers to motor vehicles that have not been put into traffic, for examples new cars that are ready to sell or vehicles used only on possession of the owner like forklift trucks.

In contrast Section 143 of the Road Traffic Act 1988 provides:

A person must not use a motor vehicle on a road or other public place unless there is in force in relation to the use of the vehicle by that person such a policy of insurance or such a security in respect of third party risks as complies with the requirements of this Part of this Act. (The Road Traffic Act 1988 Section 143)

Construction of the Road Traffic Act is slightly different from analogical act in Poland because in the UK a person who uses motor vehicle on the public places or roads must have the insurance. So as long as the person will not drive there is no obligation to have an insurance. According to The Road Traffic Act there are other situations, when there is no obligation of insurance. The exceptions are for:

- invalid carriages,

- the vehicle owned by the council of a county or county district in England and Wales, the Common Council of the City of London, the council of a London borough, the Inner London Education Authority which usage does not require insurance,

- the vehicle owned by a joint board or committee in England or Wales, or joint committee in Scotland,

- the vehicle owned by a police authority at a time when it is being driven under the owner's control when it is being driven for police purposes,

- to a vehicle at a time when it is being driven on a journey undertaken for salvage purposes refers to marine accidents pursuant to Part IX of the Merchant Shipping Act 1995,

- to a vehicle owned by a health service body,

- to an ambulance owned by a National Health Service trust,

- to an ambulance owned by an NHS foundation trust,

- to a vehicle which is made available by the Secretary of State.

- to a vehicle owned by the Care Quality Commission, at a time when the vehicle is being driven under the owner's control. (The Road Traffic Act 1988 Section 144).

According to regulations, the third party vehicle insurance in Poland covers accidents that occurs on the Polish territory and on territory of countries which accepted the Multilateral Agreement which operates within the Green Card System (The Compulsory Insurance Act Art 25). England as a part of The United Kingdom is a signatory of that agreement so damage made by Polish driver on the territory of England is compensated on the principle of reciprocity.

One of the basic features which can be compared is the sum of insurance. This sum is a maximum amount of compensation that insurance company will 
pay to someone who is indicated in an insurance policy (www.pbuk.pl; 2014). The insured sum in England is higher than the sum in Poland and it is 1000000 Pound for all damages and injuries, while in Poland it is 1000000 Euro for personal injury and 500000 Euro for property damage.

To get the full picture of legal background for insurances in both countries we have to compare regulations from Poland with regulations from England. This thesis is dedicated for obligatory motor vehicles insurances, so at the end the analysis will be narrowed only for that kind of insurance.

It have to be noticed that Polish regulations are much more stringent and precise than English. Many conditions like a period of insurance are not established in The Road Traffic Act 1988 while in Poland all terms and conditions are set out in the Compulsory Insurance Act.

Cancelation of an insurance policy in Poland is possible only under few condition. If a person insured is a company insurance policy may be cancelled in first 7 days after concluding the contract. If a person insured is a private person this period is 30 days. After that time cancelation of a policy is not available unless the vehicle is sold or totally destroyed. In England exists similar period and it is established by The Timeshare Act 1992. This period is called 14 day cooling-off period. Insurance contract can be cancelled for 14 days without any consequences. Very often is possible to cancel the insurance contract after 14 day cooling-off period but it depends only on the conditions of insurance that are negotiating individually for every insurance contract.

There are also differences between the time for payment of compensation. Article 14 of The Compulsory Insurance Act sets out that "The insurance company pays compensation within 30 days from the date of submission of the victim or the beneficiary notification of the loss." In The Road Traffic Act there are no such requirements. It proves that Polish regulations are much more precise and detailed. It is determined that in Poland legal system is based on the Roman Law where every detail should be described because it could be interpreted differently by different courts or even misinterpreted.

There is also problem when a person who is not insured makes a damage to other user of the road. The logical way would be a sue against the loss doer. But the one who made the damage could have no such amount of money to pay full compensation and the lawsuit may take a very long time. To make the life easier in such cases the compensation will be either in Poland as in England paid by the guarantee found. The name of this found in Poland is The Insurance Guarantee Found (Ubezpieczeniowy Fundusz Gwarancyjny) (The Compulsory Insurance Act 2003, article 96 and further) and in the UK The Motor Insurers Bureau (MIB) (Merkin, 2004). It has to be mentioned that The Road Traffic Act does not establishes claims procedures in contrast The Compulsory Insurance Act in Poland describes the procedure quite well. The aim of such strict regulation is a protection of victims of road traffic collisions. There is a serious problem when 
the injured person is a victim of hit-and-run driver who escaped from the place of accident. Injuries from that kind of accidents may be serious, so in both countries compensation for personal injuries are paid by the guarantee found.

\section{COMPARISON OF OBLIGATORY VEHICLE INSURANCES IN POLAND AND IN ENGLAND}

In Poland the subject of insurance is a car, unlike in England where the subject is driver. In both countries obligatory is only third party insurance, which can be extended. In England there are two basic possibilities of such enlargement: third party fire and theft and comprehensive insurance. The comprehensive insurance includes obligatory insurance and insurance against damage of the vehicle by the user or affected by other external forces. In Poland generally exists only one possibility to extend basic insurance it is called Auto Casco (AC) and it is similar to comprehensive insurance in the UK. In further part of this thesis we will focus only on the third party liability insurance.

In both countries premium is determined by the same factors (amount of damages, probability of an accident), but in the UK insurance companies ask much more detailed questions (Ogólne Warunki Ubezpieczeń Komunikacyjnych PZU Auto, 2013, and Motor Insurance Policy booklet Aviva UK, 2014). While the subject of insurance is driver it is much simpler to identify potential risks. In England insurance companies are able to build a database where all accidents of every driver will be noticed. In Poland such database is run by Insurance Guarantee Found, but it is noticed if a compensation was paid from third party liability insurance. If the subject of insurance is a car no one is able to check how many drivers may use it, especially when owner of the vehicle is a company. That causes that English insurers may estimate risk factors precisely than Polish, because in Poland it is hard to estimate how many drivers will use a vehicle.

In the table above are described frequently asked questions by the insurers. In a specific situation these questions may be a little different or asked in a different way, but most of them are basic. Table is based on insurance applications provided by Aviva Insurance Limited, Aviva Sp. z o.o., Axa UK plc., Axa Towarzystwo Ubezpieczeń i Reasekuracji S.A. and PZU S.A. In both countries can be noticed that insurer wants to know the history of claims. It may be assumed that if the driver/vehicle was involved in many accidents in the past it will cause many accidents in the future and the probability of damage in the future is high. So it is justified that history of claims is important information for insurance company and may have influence on premium. English insurers also asks about a place of keeping the vehicle at night. This fact is essential for theft insurance because it is more likely that car can be stolen from the street than form locked garage. 
The third party liability insurance covers claims made by third parties, whom the insured or policyholder caused damage or injury. The idea is very simple, but if we look at the details we can see that there are some different exclusions from insurers liability.

Table 1. The necessary information in order to conclude an insurance contract

\begin{tabular}{|c|c|}
\hline Polish insurers & English insurers \\
\hline \multicolumn{2}{|c|}{ Vehicle usage } \\
\hline $\begin{array}{l}\text { What do you use your car for? (Social, domestic } \\
\text { and Pleasure SDP; Social, domestic, pleasure and } \\
\text { commuting SDPC; Buisness use) } \\
\text { What would you say your annual mileage is? } \\
\text { Where do you keep the car at night? (Locked } \\
\text { garage; Unlocked garage; Drive; Street outside } \\
\text { home; Street away home; Other) }\end{array}$ & $\begin{array}{l}\text { Does the vehicle is used for professional use } \\
\text { as a taxi, for rent, in driving school, for racing? } \\
\text { Are there any co-owners of the vehicle? } \\
\text { Does the owner has bonuses for lack of damage }\end{array}$ \\
\hline \multicolumn{2}{|c|}{ Driver details } \\
\hline $\begin{array}{l}\text { What is employment status of a driver } \\
\text { (Employed; Self employed; Currently not } \\
\text { working; Education) } \\
\text { Does the driver have a full or provisional driving } \\
\text { license? } \\
\text { Where and when was the driving license issued? } \\
\text { (UK; EU; European non-EU; International) } \\
\text { Have the driver had an insurance policy declined, } \\
\text { cancelled, voided or had special terms imposed? } \\
\text { Have the driver had any motor accidents claims } \\
\text { or losses in the past } 5 \text { years, no matter who was at } \\
\text { fault or if claim was made? } \\
\text { Have the driver had any driving related } \\
\text { convictions, endorsements, } \\
\text { disqualifications or bans in the past } 5 \text { years? } \\
\text { Have the driver had any non-motoring-related } \\
\text { criminal convictions? } \\
\text { Are there any other drivers will use the vehicle? }\end{array}$ & $\begin{array}{l}\text { Is the vehicle used by someone under } 25 ? \\
\text { Does the owner have any discounts for non- } \\
\text { claims insurance? } \\
\text { Have the driver had any motor accidents claims } \\
\text { or losses in the past } 5 / 3 \text { years? }\end{array}$ \\
\hline \multicolumn{2}{|c|}{ Vehicle } \\
\hline $\begin{array}{l}\text { All basic information about vehicle (name, year, } \\
\text { type, registration number, engine capacity, power } \\
\text { etc...) }\end{array}$ & $\begin{array}{l}\text { All basic information about vehicle (name, } \\
\text { year, type, registration number, engine capacity, } \\
\text { power etc...) }\end{array}$ \\
\hline
\end{tabular}

S o u r ce: General Conditions of Vehicle Insurance PZU UZ/264/2013 from 30 September 2013; Motor Insurance Policy booklet Aviva UK, 2014; https://www.aviva.co.uk; http://www.pzu. pl; http://axa.co.uk; http://www.axa.pl 
Ta b l e 2. Exclusions apply to the obligatory motor insurance policy in Poland and in the UK

\begin{tabular}{|c|c|c|}
\hline English insurance & Polish insurance & Comparison \\
\hline 1 & 2 & 3 \\
\hline $\begin{array}{l}\text { Accident or loss while any } \\
\text { vehicle that is insured under } \\
\text { this policy is being used } \\
\text { otherwise than for purposes } \\
\text { described in certificate of } \\
\text { insurance. }\end{array}$ & $\begin{array}{l}\text { In polish liability insurance } \\
\text { there is no such exclusion. } \\
\text { Insurer will pay compensation } \\
\text { even if the vehicle is used in } \\
\text { a different way than the insurer } \\
\text { was informed. But in such } \\
\text { situation insurer may require } \\
\text { additional premium. }\end{array}$ & $\begin{array}{l}\text { It seems that in Poland } \\
\text { regulations are less strict, and } \\
\text { allow for the greater flexibility } \\
\text { in the use of vehicle. }\end{array}$ \\
\hline $\begin{array}{l}\text { Accident or loss made by the } \\
\text { person who is not described in } \\
\text { the certificate of insurance, or } \\
\text { does not have a valid license } \\
\text { to drive vehicle, or is not } \\
\text { complying with the terms and } \\
\text { conditions of the license. }\end{array}$ & $\begin{array}{l}\text { For the accidents made by } \\
\text { the person who has no valid } \\
\text { license to driving the vehicle. }\end{array}$ & $\begin{array}{l}\text { In Poland insurance is assigned } \\
\text { to a particular vehicle and it } \\
\text { doesn't matter who is going } \\
\text { to use it. In the UK insurance } \\
\text { is assigned to the driver and } \\
\text { vehicle. If one driver want } \\
\text { to use more than one vehicle } \\
\text { he has to pay much higher } \\
\text { premium. }\end{array}$ \\
\hline $\begin{array}{l}\text { Any consequence of war, } \\
\text { invasion, act of foreign } \\
\text { enemy, hostilities or a warlike } \\
\text { operation or operations } \\
\text { (whether war is declared or } \\
\text { not), civil war, rebellion, } \\
\text { revolution, insurrection, civil } \\
\text { common assuming the of or } \\
\text { amounting to an uprising, } \\
\text { military or usurped power and } \\
\text { any action relating to above } \\
\text { (including controlling and } \\
\text { preventing). }\end{array}$ & $\begin{array}{l}\text { The members of the military } \\
\text { armed forces are not obliged } \\
\text { to have compulsory vehicle } \\
\text { insurance. So if they made } \\
\text { a damage victim should claim } \\
\text { for compensation directly to } \\
\text { these entitles. } \\
\text { Insurance conditions do not } \\
\text { exclude the direct damage } \\
\text { caused by the war, but to } \\
\text { occur the insurer's liability } \\
\text { damage must be caused by the } \\
\text { insured and it can't be caused } \\
\text { deliberately. }\end{array}$ & $\begin{array}{l}\text { Generally in both countries } \\
\text { damages made by war are not } \\
\text { going to be compensate by the } \\
\text { insurer, but in Poland it is not } \\
\text { shown very clearly, it results } \\
\text { from the general definition of } \\
\text { liability insurance included in } \\
\text { the Compulsory Insurance Act. }\end{array}$ \\
\hline $\begin{array}{l}\text { Loss, damage, injury or death } \\
\text { directly caused by pollution or } \\
\text { contamination, or by ionizing } \\
\text { radiation and radioactive } \\
\text { substances. }\end{array}$ & $\begin{array}{l}\text { Damages consisting } \\
\text { environmental pollution } \\
\text { contamination. }\end{array}$ & $\begin{array}{l}\text { In this area insurance coverage } \\
\text { in both countries are quite } \\
\text { similar. }\end{array}$ \\
\hline $\begin{array}{l}\text { If the vehicle is registered } \\
\text { outside Great Britan }\end{array}$ & $\begin{array}{l}\text { Insurance policy is terminated } \\
\text { in the event the vehicle is } \\
\text { registered outside Poland. The } \\
\text { only exception is when owner } \\
\text { bought his vehicle in foreign } \\
\text { country and want to import it. }\end{array}$ & $\begin{array}{l}\text { In this area insurance coverage } \\
\text { is similar in Poland and in the } \\
\text { UK. }\end{array}$ \\
\hline
\end{tabular}


Table 1 cont.

\begin{tabular}{|c|c|c|}
\hline 1 & 2 & 3 \\
\hline $\begin{array}{l}\text { The death of, or injury to any } \\
\text { employee of the person insured } \\
\text { which arises out of, or in the } \\
\text { course of, that employee's } \\
\text { duties, unless the insurer must } \\
\text { provide under the Road Traffic } \\
\text { Acts. }\end{array}$ & $\begin{array}{l}\text { There is no such exclusion in } \\
\text { Poland. }\end{array}$ & $\begin{array}{l}\text { Subject of polish insurance is } \\
\text { a car, so there is no matter who } \\
\text { drives the car and who is the } \\
\text { victim of a damage. So in this } \\
\text { case coverage of insurance in } \\
\text { Poland is wider. }\end{array}$ \\
\hline $\begin{array}{l}\text { Loss or damage to property } \\
\text { that belongs or it is in the care } \\
\text { of any person insured or is } \\
\text { being carried in the vehicle. }\end{array}$ & $\begin{array}{l}\text { The damage, destruction or } \\
\text { loss of property caused by the } \\
\text { driver the user or owner of } \\
\text { a motor vehicle. } \\
\text { Damages in transit fee charges, } \\
\text { consignments or luggage. }\end{array}$ & $\begin{array}{l}\text { Either in Poland and in the } \\
\text { UK situation is similar. If the } \\
\text { vehicle make a loss in property } \\
\text { that belongs to person insured } \\
\text { insurance company will not } \\
\text { pay the compensation. }\end{array}$ \\
\hline $\begin{array}{l}\text { Loss, damage, death or injury } \\
\text { while any motor vehicle is } \\
\text { being used on an aerodrome } \\
\text { or airport for aircraft taking } \\
\text { off or landing, aircraft parking } \\
\text { areas including service roads, } \\
\text { ground equipment parking } \\
\text { areas or any parts of passenger } \\
\text { terminals within the customs } \\
\text { examination area. }\end{array}$ & $\begin{array}{l}\text { There is no such exclusion. } \\
\text { But the sum of insurance } \\
\text { is limited, so if the vehicle } \\
\text { make an airplane catastrophe } \\
\text { with many victims the sum of } \\
\text { insurance will not be sufficient. }\end{array}$ & $\begin{array}{l}\text { Polish insurance coverage is } \\
\text { wider in this area. }\end{array}$ \\
\hline $\begin{array}{l}\text { Any deliberate act or omission } \\
\text { by the persons insured. }\end{array}$ & $\begin{array}{l}\text { Gross negligence and damage } \\
\text { caused intentionally. }\end{array}$ & $\begin{array}{l}\text { In this area insurance coverage } \\
\text { is similar. }\end{array}$ \\
\hline
\end{tabular}

S o u r c e: Motor Insurance Policy Terms and Conditions Aviva Insurance Limited and the Compulsory Insurance Act and Terms and Conditions of a vehicle insurance Aviva Sp. z o.o.

Comparison of insurance coverage by the third party liability insurances provided by Aviva Sp. z o.o. (in Poland), and Aviva Insurance Limited (in England) shows that wider coverage is offered by the Polish insurer. This is a consequence of, inter alia, assumed system of insurance, where the subject insured is vehicle, and every user, who is going to drive the car is covered by the insurance. Insurance company has possibility to check who uses the vehicle, the only restriction is to obtain the consent of the owner of vehicle. So there is no matter that one vehicle can be used by many employees of the car's owner. In England situation is different. Only the person insured can use the vehicle. If there are other drivers it have to be entered into the policy, and it require higher premium. Very interesting case is when damage is caused while motor vehicle is being used on an aerodrome or airport for aircraft taking off or landing. In England insurance company has excluded that case from the scope of insurance. In contrast Polish insurance 
company has no such exclusions. In other areas of insurance there are very small differences of details, which are shown in the table 2.

A coverage of insurance is wider in Poland than in England. So it may seem that insurance in Poland should be more expensive, but that is not true. Insurance premium is much lower in Poland. For the purposes of this study were estimated prices of insurances for Peugeot 206 from 2006 which is worth about 2000 GBP. It is assumed that the vehicle will be used only by one 30 year old driver, who is employed and park his car on the street. The owner has no noclaim discounts, because this is his first vehicle, but he has a driving license for 10 years. In Poland cost of such insurance in Aviva Sp. z o.o. is 791 PLN (online calculation on www.aviva.pl) and in Aviva Insurance Limited is $846 \mathrm{GBP}$ (4831,13PLN) (online calculation on http://www.aviva.co.uk). So the premium is five times bigger in England than in Poland. From the information that I get from underwriters working for PZU S.A. there are three most important parts of a premium. The price of insurance results from that the premium must pay for potential compensation, costs of administration and customer service and in the end there have to be some profit for insurance company. It is very difficult to compare the average compensation paid in Poland and in England, but usually repair costs are higher in England than in Poland because of higher labor costs (http://ec.europa.eu/eurostat). The same situation is with costs of medical care for victims in England, so lower premium rates in Poland can be reliable.

Processing of a claim is one of the most important issues for people who suffered during a road accident. The victim of a road traffic accident should get indemnity from insurance company quickly and in amount according to the damage. It is very important that the loss compensation process be short. The faster victim will get compensation the better insurance system is perceived by people. If we comprise obligatory vehicle insurances provided by Polish insurer Aviva Sp. z o.o. and English Aviva Insurance Limited we can say that making a claim is similar in Poland and in England. Just after the accident drivers call for police or prepare statement of the collision. Later they make a claim in an insurance company and insurer examine the case and decide to accept or refuse responsibility. But there are some details that makes difference between making a claim in Poland and in England.

A. In England there is no fixed time for insurance company to refuse or pay compensation. In Poland government regulations imposes on all insurance companies limit of 30 after reporting a claim (W jakim terminie zakład ubezpieczeń ma obowiązek wypłaty odszkodowania, rzu.gov.pl, 2015). That means that insurer have to decide about right to compensation and establish the amount to pay. This period may be extended only when reasonable circumstances makes the decision impossible. But in that situation insurer is obliged to inform the victim and parties of an insurance contract, and end the case not later than 14 days after removal the obstacles that made the decision impossible. In England there is no such fixed 
regulations. It is said that insurance company should make the decision about compensation without undue delay.

B. The method of compensation seems to be the same in both countries, but there are some small differences. English insurers has much more developed network of workshops. In that workshops victim can repair destroyed car without any costs. In Poland there are such networks, but only the biggest insurance companies have developed them satisfactorily. Most insurance companies in Poland prefer method of compensation based on estimate of costs of repairs made by the insurance companies. It is usually much lower than costs of repair in services authorized by the vehicle manufacturers. But proposed valuation is usually efficient to repair vehicle by the victim himself.

C. Complaints procedure is different in both countries. Most insurance companies in Poland response for complaints for less than 30 days. In England every insurance company has their own procedure. For example Aviva Insurance Limited declares resolving every complain quickly. It means that insurer will contact with complainant within 10 days of receipt and give an expected date response.

In practice it is much easier to get compensation from Polish insurer than from English. In both countries when accident occurs drivers should make a statements with loss description. But the difference is when collision participants do not agree about who is the culprit. In Poland in such situation there is possibility to call the police. The police solves the dispute and indicates the culprit. Of course if some participant does not agree with police statement he can appeal but then the case will be brought to court by the police. In England it has no matter if one of the participants will plead guilty. The compensation is paid by the insurance company and the insurer have to accept that his client is guilty. If the insurance company does not doing that, or the sufferer does not accept the decision of insurer, the case have to be brought to the court.

\section{REFERENCES}

\section{Books and articles}

Banasiński, Antoni. 1996. Ubezpieczenia gospodarcze. Warszawa: Poltext.

Drozdowska-Iwanicz, Małgorzata. 2013. Ubezpieczenia. Warszawa: Polskie Wydawnictwo Ekonomiczne.

Jerry, Robert H. II, D.R. Richmond. 2012. Understanding Insurance Law. Fifth edition. Lexis Nexis.

Kowalewski, Eugeniusz. 2006. Prawo Ubezpieczeń Gospodarczych. Bydgoszcz: Oficyna Wydawnicza Branta.

Ludwichowska, Katarzyna. 2011. Kompensacja szkód komunikacyjnych [Traffic Accident Compensation]. Warszawa: Poltext.

Merkin, Robert. M., Jeremy Stuart-Smith. 2004. The Law of Motor Insurance. London: Sweet \& Maxwell.

Merkin, Robert M., Iain Goldrein, Jonathan Mance. 2012. Insurance Disputes. London: Informa.

Merkin, Robert M., Johanna Hjalmarsson. 2007. Compendium of Insurance Law. London: Informa. 
Polish Insurance Market. Statistical analyses and studies. 2013. Warszawa: Główny Urząd Statystyczny.

Scales, Adam F. 2000. "Man, God and the Serbonian Bog. The Evolution of Accidential Death Insurance". Iowa Law Review 173.

Szczęśniak, Marian 2012 "Historia ubezpieczeń polskich po II wojnie światowej”. Cz. 1. "Okres monopolu ubezpieczeń państwowych". Monitor Ubezpieczeniowy 51, grudzień.

Szczęśniak, Marian. 2013. "Historia ubezpieczeń polskich po II wojnie światowej”. Cz. 2. "Ubezpieczenia polskie w okresie transformacji". Monitor Ubezpieczeniowy 52, marzec.

Zimoch-Tucholka, Julita, Domański, Zakrzewski, Palinka. 2008 „International Insurance Law And Regulation. Poland". Oceana, April 2008.

\section{Legal acts}

Ogólne warunki ubezpieczeń komunikacyjnych PZU Auto ustalone uchwałą Zarządu PZU S.A. nr UZ/264/2013 z dnia 30 września 2013.

The Act of 18 September 2001 - The Marine Code [Kodeks Morski]. Dz. U. 2001, nr 138, poz. 1545.

The Act of 21 July 2006 on Financial Market Supervision [Ustawa z dnia 21 lipca 2006 roku o nadzorze nad rynkiem finansowym]. Dz. U. 2006, Nr 157, poz. 1119.

The Act of 22 May 2003 on Compulsory Insurance, the Insurance Guarantee Fund, and the Polish Motor Insurance Bureau [Ustawa z dnia 22 maja 2003 o ubezpieczeniach obowiązkowych, Ubezpieczeniowym Funduszu Gwarancyjnym i Polskim Biurze Ubezpieczycieli Komunikacyjnych]. Dz. U. 2003, nr 124, poz. 1152.

The Act of 22 May 2003 on Insurance Activity [Ustawa z dnia 22 maja 2003 roku o działalności ubezpieczeniowej]. Dz. U. 2003, nr 124, poz. 1151.

The Act of 22 May 2003 on Insurance Intermediation [Ustawa z dnia 22 maja 2003 roku o pośrednictwie ubezpieczeniowym]. Dz. U. 2003, nr 124, poz. 1154.

The Act of 23 April 1964 Civil Code [Ustawa z dnia 23 kwietnia 1964 - Kodeks Cywilny]. Dz. U. 1964, nr 16, poz. 93.

The Consumer Insurance (Disclosure and Representatives) Act 2012, c. 6.

The Financial Services Act 2012, c. 21.

The Financial Services and Market Act 2000, c. 8.

The Insurance Companies (Reserves) Act 1995, c. 29.

The Marine Insurance Act 1906, c. 41.

The Road Traffic Act 1988, c. 52.

The Third parties (Rights against insurance) Act 2010, c. 10.

The Timeshare Act 1992, c. 35.

\section{Internet sources}

A Brief History of Insurance; Randmark 40 Insurance Data Platforms. http://www.randmark40. com/index.php?option $=$ com content\&view $=$ article\&id=33\&Itemid $=56$ [access 18.12.2014, 18: 39].

Equitable Life and Casualty Insurance Company. http://www.equitable.co.uk/about-us/history-andfacts/ [access 13.01.2015, 12: 13].

Polish Insurance Chamber, article based on "185 lat ubezpieczeń gospodarczych w Polsce", Warszawa 1988. https://www.piu.org.pl/public/upload/ibrowser/historia_ubezpieczen__na_ swiecie_i_w_polsce.pdf [access 10.11.2014, 22: 20].

The Consumer Insurance Act - Interpretation of the law. http://www.out-law.com/page-11391 [access 24.12.2014, 11: 14]. 


\section{Sebastian Barszowski}

\section{PORÓWNANIE PRAWNYCH ASPEKTÓW WYBRANYCH PRODUKTÓW UBEZPIECZENIOWYCH NA RYNKU POLSKIM I BRYTYJSKIM}

Streszczenie. W niniejszej pracy autor podjął się próby porównania prawnych aspektów ubezpieczeń odpowiedzialności cywilnej posiadacza pojazdu mechanicznego w Polsce i w Anglii. Temat ten jest na tyle złożony, że jeszcze nikt nie dokonał porównania systemów ubezpieczeń tych dwóch krajów. Autor stanął przed nie lada wyzwaniem, którego celem było porównanie polskich regulacji prawnych dotyczących ubezpieczeń komunikacyjnych z brytyjskimi, dzięki czemu można określić stopień rozwoju polskiego rynku ubezpieczeniowego, który jest stosunkowo młody w porównaniu z brytyjskim. Cel ten został osiaggnięty. Badanie wykazało, że istnieją znaczące różnice między analizowanymi systemami ubezpieczeń, jednak przepisy nie hamują rozwoju ubezpieczeń w żadnym z tych krajów. W początkowej części pracy autor skupił się na historii ubezpieczeń i zarządzania ryzykiem, a następnie przeszedł do porównania systemów obowiązkowych ubezpieczeń komunikacyjnych w Polsce i w Anglii.

Słowa kluczowe: odpowiedzialność osoby trzeciej, ubezpieczenia, ubezpieczenie obowiązkowe. 